\title{
A Cross-sectional Study on the Occurrence of Coxiella burnetii Infection in a Dairy Farm, Bareilly, India
}

\author{
Manesh Kumar ${ }^{1 *}$, Satyaveer Singh Malik ${ }^{1}$, Sunitha Ramanjeneya ${ }^{1}$, \\ Radhakrishna Sahu ${ }^{1}$, Jess Vergis ${ }^{1}$, Richa Pathak ${ }^{1}$, Pankaj Dhaka ${ }^{1}$, Jay Prakash Yadav ${ }^{1}$, \\ Sukhadeo Baliram Barbuddhe ${ }^{2}$ and Deepak Bhiwa Rawool ${ }^{{ }^{*}}$
}

\author{
${ }^{1}$ Division of Veterinary Public Health, ICAR-Indian Veterinary Research Institute, \\ Uttar Pradesh- 243 122, India \\ ${ }^{2}$ ICAR-National Research Centre on Meat, Chengicherla, Telangana- 500 092, India
}

*Corresponding author

\section{A B S T R A C T}

\begin{tabular}{|l}
\hline Ke y w or d s \\
$\begin{array}{l}\text { Coxiella burnetii, Q } \\
\text { fever, Cattle, Dairy } \\
\text { farm, PCR }\end{array}$ \\
\hline Article Info \\
\hline $\begin{array}{l}\text { Accepted: } \\
\text { 15 January } 2019 \\
\text { Available Online: } \\
\text { 10 February } 2019\end{array}$ \\
\hline
\end{tabular}

Keywords

Coxiella burnetii, Q fever, Cattle, Dairy arm, PCR

Q fever is highly infectious bacterial zoonoses caused by Coxiella burnetii and remains largely neglected and underreported in various states of India. The present cross-sectional study employing a simple random sampling approach analysed a total of 324 samples (108 blood, 108 sera and 108 vaginal swabs) from cattle $(n=108)$ employing of PCR and ELISA of cattle dairy farm from Bareilly, Uttar Pradesh, India. Besides, 18 environmental samples (animal feed-05, soil-04, drainage water-05 and drinking water-04) from the premises of the farm were also collected. On screening of cattle samples by trans-PCR and com1-PCR revealed positivity for $C$. burnetii DNA in $9.25 \%(10 / 108)$ and $5.55 \%(6 / 108)$ samples of cattle blood; $12.03 \%(13 / 108)$ and $5.55 \%(6 / 108)$ of sera, and $12.96 \%(14 / 108)$ and $06.48 \%(7 / 108)$ of vaginal swabs, respectively. Screening of cattle on the farm by commercial i-ELISA kit revealed antibodies against $C$. burnetii in the serum samples of $14.81 \%(16 / 108)$ cattle population.

\section{Introduction}

Q fever is a highly infectious disease of great public health importance caused by obligate intracellular, Gram negative bacterium Coxiella burnetii, which can successfully infect hosts ranging from mammals including domestic animals, humans and wildlife as well as reptiles, fish, birds, ticks and arthropods (Angelakis and Raoult, 2010; Cutler et al., 2010; Vanderburg et al., 2014; Eldin et al., 2017).
The C. burnetii infections in animals generally known as 'Coxiellosis' are widespread in domestic ruminants, which serve as the major reservoirs of the pathogen. The disease in ruminants is frequently subclinical, but late abortions, stillbirths and reproductive disorders can occasionally be observed (Maurin and Raoult, 1999; ArricauBouvery and Rodolakis, 2005). The potential risk arising from cattle has found greater than that from small ruminants, as cattle not only excreted more number of pathogens but their 
shedding in milk also lasted for a longer period (Rodolakis et al., 2007).

Due to the limited diagnostic capacities, epidemiological studies on Q fever in India in general are very few (Vaidya et al., 2010; Malik et al., 2013; Stephen et al., 2014; Kumar et al., 2017; Mohan et al., 2017; Dhaka et al., 2017, Sahu et al., 2018). It is in this context that the present study was envisaged to assess the occurrence of $\mathrm{Q}$ fever in a dairy farm, Bareilly, Uttar Pradesh, India.

\section{Materials and Methods}

A cross-sectional study with simple random sampling was conducted in a dairy farm of Bareilly district, Uttar Pradesh, India. A total of 324 samples (108 blood, 108 sera and 108 vaginal swabs) were collected from 108 cattle for screening of $C$. burnetii infection in the dairy herd. Additionally, 18 environmental samples (animal feed-05, soil-04, drainage water-05 and drinking water-04) from the premises of the farm were also collected for detection of $C$. burnetii. All the samples were aseptically collected in sterile containers and were transported to laboratory under chilled conditions. Blood, vaginal swabs and environmental samples were stored at refrigeration temperature, while, serum samples were stored at $-20^{\circ} \mathrm{C}$ until further use.

Genomic DNA was isolated and purified from the blood samples of both cattle and human using Qiagen blood and tissue kit (Qiagen, Germany) as per the manufacturer's instructions. The processing of vaginal swab samples for screening by PCR assay was carried out as described by Berri et al., (2000), according to which a simple boiling method was sufficient for DNA extraction from the vaginal swabs for analyzing it by PCR assay. It is noteworthy here that the boiling inactivates $C$. burnetii in sample, minimizes the risk to the laboratory personnel, and also remains an inexpensive procedure compared to other methods (Berri et al., 2000). In brief, a sample of genital swab was vigorously shaken in $1 \mathrm{ml}$ of PBS solution. The solution $(200 \mu \mathrm{l})$ was then boiled for $10 \mathrm{~min}$ and centrifuged at 13,000 x $\mathrm{g}$ for $5 \mathrm{~min}$ and then collected supernatant was used for the PCR assays. The environmental and feed samples were processed as per the method described by Fitzpatrick et al., (2010). In brief, $5 \mathrm{~g}$ of samples were mixed with 10 to $30 \mathrm{ml}$ of Phosphate buffer saline (PBS) solution to create homogenized slurry, which was kept for $1 \mathrm{~h}$ at room temperature and then centrifuged for $5 \mathrm{~min}$ at $123 \mathrm{xg}$. The supernatant was removed and centrifuged at $20,000 \mathrm{xg}$ for $15 \mathrm{~min}$. The supernatant was then carefully discarded and the pellet was resuspended in $1 \mathrm{ml}$ of PBS solution. Finally, $700 \mu \mathrm{l}$ of the re-suspended pellet was processed for DNA extraction using Qiagen Stool kit (Qiagen, USA). Following DNA extraction, purity of extracted DNA was checked using a Biospectrometer (Eppendorf $\mathrm{GmbH}$, Germany). DNA with an absorption ratio $\left(\mathrm{A}_{260} / \mathrm{A}_{280}\right)$ of more than or equal to 1.80 were desirable for PCR assay. The DNA of standard $C$. burnetii Nine Mile strain was thankfully received from Dr. Eric Ghigo, URMITE-IRD, Faculté de Médecine, France.

The detection of pathogen in all the collected samples was carried out by PCR employing trans and com 1 genes. The trans-PCR assay was performed targeting transposons-like regions in chromosomal DNA using, trans-1 (5'-TAT GTA TCC ACC GTA GCC AGT C$\left.3^{\prime}\right)$ and trans-2 (5'-CCC AAC AAC ACC TCC TTA TTC-3') with an expected amplicon size of 687 bp (Berri et al., 2000) while, com1-PCR was performed using primers com 1-F (5'AGTAGAAGCATCCCAAGC ATTG-3') and com 1-R (5'TGCCTGCTAGCTGT 
AACGATTG -3') with an expected amplicon size of 501 bp (Zhang et al., 1998). The cycling conditions for trans 1 and 2 primers were standardised at $94^{\circ} \mathrm{C}$ for $5 \mathrm{~min}$ (initial denaturation), followed by 40 cycles of $94^{\circ} \mathrm{C}$ for $30 \mathrm{~s}$ (denaturation), $52^{\circ} \mathrm{C}$ for $1 \mathrm{~min}$ (annealing), $72^{\circ} \mathrm{C}$ for $1 \mathrm{~min}$ (extension), and an final extension $72^{\circ} \mathrm{C}$ for $10 \mathrm{~min}$. The cycling conditions for coml included an initial denaturation of DNA at $95^{\circ} \mathrm{C}$ for $5 \mathrm{~min}$ followed by 30 cycles, each consisting of denaturation at $95^{\circ} \mathrm{C}$ for $30 \mathrm{~s}$, annealing at $63^{\circ} \mathrm{C}$ for $1 \mathrm{~min}$ and extension at $72^{\circ} \mathrm{C}$ for 1 min. A final extension was provided at $72^{\circ} \mathrm{C}$ for 10 min followed by holding the tubes at $4^{\circ} \mathrm{C}$. The DNA of $C$. burnetii Nine Mile 1 strain was used as a positive control whereas, Nuclease free water (Thermoscientific, USA) served as negative template control. The resultant PCR products were visualized after electrophoresis using gel documentation system (UVP Gel Seq Software). The sera samples obtained from cattle were screened using commercial i-ELISA kits (Bio-X Diagnostics, Rochefort, Belgique) as per manufacturer's instructions.

\section{Results and Discussion}

The results of 324 clinical samples (blood108, serum-108 and vaginal swabs-108) collected from cattle $(n=108)$, as well as environmental samples $(n=18)$ from the dairy farm, screened for coxiellosis are summarized in tabular form (Table 1). The trans-PCR assay targeting IS1111 gene of C. burnetii in the DNA of cattle $(n=108)$ showed the presence of pathogen in $12.03 \%(13 / 108)$ blood samples, $09.25 \%$ sera $(10 / 108)$ and $12.96 \%$ (14/108) vaginal swabs, respectively (Table 1); while the com1-PCR assay targeting coml, the single copy gene of $C$. burnetii, could detect the pathogen in lesser number of samples, with a positivity recorded as $05.55 \%(6 / 108)$ in blood samples, $05.55 \%$ $(6 / 108)$ sera and $06.48 \%$ (7/108) vaginal swabs (Table 1). All the samples collected from environment $(n=18)$ of the farm tested negative in both the PCR assays (Table 1). The commercial ELISA kit revealed seropositivity for coxiellosis in $14.81 \%$ $(16 / 108)$ of cattle on the dairy farm.

In the present study, a higher detection rate of pathogen in cattle blood samples by transPCR assay observed to the tune of $12.03 \%$ (13/108), and $12.96 \%$ (14/108) in blood/sera samples and vaginal swabs, respectively; as compared to $05.55 \%$ (6/108), and $06.48 \%$ (7/108) by com1-PCR assay, respectively. It can be attributed to the reported higher sensitivity of the former assay targeting IS1111 gene, a multi-copy gene having 7-110 copies per isolate of $C$. burnetii (Klee et al, 2006), as compared to the latter test targeting coml gene, reported as a single-copy gene (Kersh et al., 2012). These observations corroborates with some earlier reported findings about the higher sensitivity of transPCR than com1-PCR, wherein the pathogen detection in clinical samples by these tests has been reported as $59 \%$ and $44 \%$ (Turra et al., 2006), 63\% and 30\% (Kersh et al., 2012), $64 \%$ and $10 \%$ (Shapiro et al., 2016), respectively.

The negativity of all the environmental samples collected from premises of all the three gaushalas in PCR assays observed in our study might be either due to the absence of the organism in these samples, or nonshedding of the pathogen in vaginal mucous in recent past, or any possible PCR inhibition in the environmental samples, as has been experienced in some earlier studies related to the screening of environmental samples (Abolmaaty et al., 2007; de Bruin et al., 2011).

The detection of antibodies against $C$. burnetii by commercial ELISA kit in $14.81 \%(16 / 108)$ of serum samples of cattle is in accordance 
with earlier studies, wherein the prevalence of bovine coxiellosis has been reported to range from $5.55 \%$ to $29.9 \%$ (Kaplan and Bertagna, 1955; Joshi et al., 1978; Vaidya et al., 2010; Malik et al., 2013; Das et al., 2014), however, it was lower than the median prevalence of $C$. burnetii infection among cattle reported as $19.4 \%$ at the animal level and $37.7 \%$ at the herd level (Guatteo et al., 2011).

Table.1 Results of sample screening by PCR assays and ELISA for coxiellosis at Cattle Dairy farm (Bareilly, Uttar Pradesh)

\begin{tabular}{|c|c|c|c|c|c|}
\hline \multirow[t]{3}{*}{ Category } & \multirow{3}{*}{$\begin{array}{l}\text { Types of } \\
\text { samples }\end{array}$} & \multirow{3}{*}{$\begin{array}{l}\text { Samples } \\
\text { screened }\end{array}$} & \multicolumn{3}{|c|}{ Positivity for coxiellosis by different tests } \\
\hline & & & \multicolumn{2}{|c|}{ PCR assays } & \multirow{2}{*}{$\begin{array}{c}\text { ELISA } \\
\% \text { (positive) }\end{array}$} \\
\hline & & & $\begin{array}{l}\text { Trans-PCR } \\
\% \text { (positive) }\end{array}$ & $\begin{array}{l}\text { Com 1-PCR } \\
\% \text { (positive) }\end{array}$ & \\
\hline \multirow[t]{3}{*}{ Cattle (108) } & Blood & 108 & $09.25 \%(10 / 108)$ & $05.55 \%(6 / 108)$ & NA \\
\hline & Serum & 108 & $12.03 \%(13 / 108)$ & $05.55 \%(6 / 108)$ & $14.81 \%(16 / 108)$ \\
\hline & Vaginal swabs & 108 & $12.96 \%(14 / 108)$ & $06.48 \%(7 / 108)$ & NA \\
\hline \multirow{4}{*}{$\begin{array}{l}\text { Environmental } \\
\text { samples (18) }\end{array}$} & Feed & 5 & - & - & NA \\
\hline & Soil & 4 & - & - & NA \\
\hline & Water & 4 & - & - & NA \\
\hline & Sewage & 5 & - & - & NA \\
\hline
\end{tabular}

In conclusion, screening of dairy Farm by trans-PCR and com1-PCR revealed positivity for C. burnetii DNA in $9.25 \%(10 / 108)$ and $5.55 \%(6 / 108)$ samples of cattle blood; $12.03 \%(13 / 108)$ and $5.55 \%(6 / 108)$ of sera, and $12.96 \%(14 / 108)$ and $06.48 \%(7 / 108)$ of vaginal swabs, respectively. Screening of cattle on the farm by commercial i-ELISA kit revealed antibodies against $C$. burnetii in the serum samples of $14.81 \%(16 / 108)$ cattle population. We further propose to undertake more number of epidemiological investigations particularly in farms to identify possible risk factors that facilitate the transmission of this agent.

\section{Acknowledgement}

The authors thank Director, ICAR- Indian Veterinary Research Institute, Izatnagar for providing facilities to carry out the research. The research is supported by grants from the Indian Council of Agricultural ResearchOutreach Programme on Zoonotic Diseases (Grant no.1000494) to SVS-M. The technical assistance by Mr. K.K. Bhat and Dr. Deepa Ujjawal is duly acknowledged.

\section{References}

Abolmaaty A., Gu W., Witkowsky R. and Levin R. E. 2007. The use of activated charcoal for the removal of PCR inhibitors from oyster samples. $J$. Microbiol. Methods. 68: 349-352.

Angelakis, E. and Raoult, D. 2010. Q Fever. Vet. Microbiol. 140: 297-309.

Arricau-Bouvery N., Rodolakis A. 2005. Is Q fever an emerging or re-emerging zoonosis? J Vet Res 36: 327-49.

Berri M, Laroucau K, Rodolakis A. (2000) The detection of Coxiella burnetii from ovine genital swabs, milk and faecal samples by the use of a single touchdown polymerase chain reaction. Vet Microbiol., 72: 285-93.

Cutler, S.J., Bouzid, M. and Cutler, R.R. 2007. Q fever. J. Infect. 54: 313-318.

Das D.P., Malik S.V., Rawool D.B., Das S., Shoukat S., Gandham R.K., Saxena S., 
Singh R., Doijad S.P., Barbuddhe S.B. 2014. Isolation of Coxiella burnetii from bovines with history of reproductive disorders in India and phylogenetic inference based on the partial sequencing of IS1111 element. Infect Genet Evol 22: 67-71.

De Bruin A., De Groot A., De Heer L., Bok J., Wielinga P.R., Hamans M., Van Rotterdam B.J., Janse I. 2011. Detection of Coxiella burnetii in complex matrices by using multiplex quantitative PCR during a major $\mathrm{Q}$ fever outbreak in The Netherlands. Appl Environ Microbiol 77: 6516-23.

Dhaka P., Malik S.S., Yadav J.P., Kumar M., Vergis J., Sahu R., John L., Barbuddhe S.B., Rawool D.B. 2017. Seroscreening of lactating cattle for coxiellosis by trans-PCR and commercial ELISA in Kerala, India. $J$ Exp Biol 5: 3.

Eldin C., Mélenotte C., Mediannikov O., Ghigo E., Million M., Edouard S., Mege J.L., Maurin M., Raoult D. 2017. From Q fever to Coxiella burnetii infection: a paradigm change. Clin Microbiol Rev 30:115-90.

Fitzpatrick K.A., Kersh G.J., Massung R.F. (2010) Practical method for extraction of PCR-quality DNA from environmental soil samples. Appl Environ Microbiol 76: 4571-3.

Guatteo, R., Seegers, H., Taurel, A.F., Joly, A. and Beaudeau, F. 2011. Prevalence of Coxiella burnetii infection in domestic ruminants: A critical review. Vet. Microbiol. 149(1-2): 1-16.

Huggett, J.F., Novak, T., Garson, J.A., Green, C., Morris-Jones, S.D., Miller, R.F. and Zumla, A. 2008. Differential susceptibility of PCR reactions to inhibitors: an important and unrecognized phenomenon. BMC Res. Notes. 1(1): 70.

Joshi, M.V. and Padbidri, V.S., 1978.
Serological survey for rickettsial infections amongst the human and domestic animal populations of Jammu and Kashmir. Indian J. Microbiol. 18: 170-172.

Kaplan, M.M. and Bertagna, P. 1955. The geographical distribution of $\mathrm{Q}$ fever. Bull World Health Organ. 13: 829860.

Kersh G.J., Lambourn D.M., Raverty S.A., Fitzpatrick K.A., Self J.S., Akmajian A.M., Jeffries S.J., Huggins J., Drew C.P., Zaki S.R., Massung R.F. (2012) Coxiella burnetii infection of marine mammals in the Pacific Northwest, 1997-2010. J Wildl Dis 48: 201-6.

Klee S.R., Tyczka J., Ellerbrok H., Franz T., Linke S., Baljer G., Appel B. (2006) Highly sensitive real-time PCR for specific detection and quantification of Coxiella burnetii. BMC Microbiol 6: 2.

Kumar S., Gangoliya S.R., Alam S.I., Patil S., Ajantha G.S., Kulkarni R.D., Kamboj D.V. 2017. First genetic evidence of Coxiella burnetii in cases presenting with acute febrile illness, India. $J$ Med Microbiol 66: 388-90.

Malik S.S., Das D.P., Rawool D., Kumar A., Suryawanshi R.D., Negi M., Vergis J., Doijad S., Barbuddhe S.B. 2013. Screening of foods of animal origin for Coxiella burnetii in India. $A d v$ Anim Vet Sci 1: 08-27.

Malik, S.V.S., Das, D.P., Rawool, D.B., Kumar, A., Suryawanshi, R.D., Negi, M., Vergis, J., Doijad, S. and Barbuddhe, S. B. 2013. Screening of foods of animal origin for Coxiella burnetii in India. Adv. Anim. Vet. Sci. 1: 107-110.

Maurin, M. and Raoult, D. 1999. Q. Fever. Clin. Microbiol Rev. 12: 518-553.

Mohan V., Nair A., Kumar M., Dhaka P., Vergis J., Rawool D.B., Malik S.S. 2017. Seropositivity of goats for 
coxiellosis in Bareilly region of UP India. Adv Anim Vet Sci 5: 226-28.

Rodolakis A., Berri M., Hechard C., Caudron C., Souriau A., Bodier C.C., Blanchard B., Camuset P., Devillechaise P., Natorp J.C., Vadet J.P. 2007. Comparison of Coxiella burnetii shedding in milk of dairy bovine, caprine, and ovine herds. $J$ Dairy Sci 90: 5352-60.

Sahu R., Kale S.B., Vergis J, Dhaka P., Kumar M., Choudhary M., Jain L., Choudhary B.K., Rawool D.B., Chaudhari S.P., Kurkure N.V. 2018. Apparent prevalence and risk factors associated with occurrence of Coxiella burnetii infection in goats and humans in Chhattisgarh and Odisha, India. Comp Immunol Microbiol Infect Dis 60: 46-51.

Shapiro, A.J., Norris, J.M., Heller, J., Brown, G., Malik, R. and Bosward, K.L. 2016. Seroprevalence of Coxiella burnetii in Australian dogs. Zoonoses Public Health. 63(6):.458-466.

Stephen S., Sangeetha B., Antony P.X. 2014. Seroprevalence of coxiellosis (Q fever) in sheep \& goat in Puducherry
\& neighbouring Tamil Nadu. Indian $J$ Med Res 140: 785.

Turra, M., Chang, G., Whybrow, D., Higgins, G. and Qiao, M. 2006. Diagnosis of acute Q fever by PCR on sera during a recent outbreak in rural South Australia. Ann. N. Y. Acad. Sci. 1078(1): 566-569.

Vaidya V.M., Malik S.V., Bhilegaonkar K.N., Rathore R.S., Kaur S., Barbuddhe S.B. 2010. Prevalence of Q fever in domestic animals with reproductive disorders. Comp Immunol Microbiol Infect Dis 33: 307-21.

Vanderburg S., Rubach M.P., Halliday J.E., Cleaveland S., Reddy E.A., Crump J.A. 2014. Epidemiology of Coxiella burnetii infection in Africa: a OneHealth systematic review. PLoS Negl Trop Dis 8: e2787.

Zhang G.Q., Nguyen S.V., To H., Ogawa M., Hotta A., Yamaguchi T., Kim H.J., Fukushi H., Hirai K. (1998) Clinical evaluation of a new PCR assay for detection of Coxiella burnetii in human serum samples. $J$ Clin Microbiol., 36:77-80.

\section{How to cite this article:}

Manesh Kumar, Satyaveer Singh Malik, Sunitha Ramanjeneya, Radhakrishna Sahu, Jess Vergis, Richa Pathak, Pankaj Dhaka, Jay Prakash Yadav, Sukhadeo Baliram Barbuddhe and Deepak Bhiwa Rawool. 2019. A cross-sectional Study on the Occurrence of Coxiella burnetii Infection in a Dairy Farm, Bareilly, India. Int.J.Curr.Microbiol.App.Sci. 8(02): 2102-2107. doi: https://doi.org/10.20546/ijcmas.2019.802.243 